\title{
Genetic Vaccination against Experimental Infection with Myotropic Parasite Strains of Trypanosoma cruzi
}

\author{
Adriano Fernando Araújo, ${ }^{1,2}$ Gabriel de Oliveira, ${ }^{3}$ Juliana Fraga Vasconcelos, \\ Jonatan Ersching, ${ }^{1,2}$ Mariana Ribeiro Dominguez, ${ }^{1,2}$ José Ronnie Vasconcelos, ${ }^{1,2,6}$ \\ Alexandre Vieira Machado, ${ }^{7}$ Ricardo Tostes Gazzinelli, ${ }^{7,8,9}$ Oscar Bruna-Romero, ${ }^{10}$ \\ Milena Botelho Soares, ${ }^{4,5}$ and Mauricio Martins Rodrigues ${ }^{1,2}$ \\ ${ }^{1}$ Centro de Terapia Celular e Molecular (CTCMol), Escola Paulista de Medicina, UNIFESP, Rua Mirassol, \\ 207 04044-010 São Paulo, SP, Brazil \\ ${ }^{2}$ Departmento de Microbiologia, Imunologia e Parasitologia, Escola Paulista de Medicina, Universidade Federal de São Paulo, \\ Rua Mirassol, 207 04044-010 São Paulo, SP, Brazil \\ ${ }^{3}$ Laboratório Biologia Celular, Instituto Oswaldo Cruz (FIOCRUZ), Avenida Brasil, 4365-Manguinhos, \\ 21040-360 Rio de Janeiro, RJ, Brazil \\ ${ }^{4}$ Centro de Pesquisas Gonçalo Moniz, FIOCRUZ, Rua Waldemar Falcão, 121, 40296-710 Salvador, BA, Brazil \\ ${ }^{5}$ Hospital São Rafael, Avenida São Rafael 2152, São Marcos, 41253-190 Salvador, BA, Brazil \\ ${ }^{6}$ Departamento de Biociências, Instituto de Saúde e Sociedade, UNIFESP, Campus Baixada Santista, 11015-020 Santos, SP, Brazil \\ ${ }^{7}$ Centro de Pesquisas René Rachou, FIOCRUZ, Avenida Augusto de Lima 1.715, Barro Preto, 30190-002 Belo Horizonte, MG, Brazil \\ ${ }^{8}$ Departamento de Bioquímica e Imunologia, Instituto de Ciências Biológicas, Universidade Federal de Minas Gerais, \\ Avenida Presidente Antônio Carlos, 6627, Pampulha, 31270-901 Belo Horizonte, MG, Brazil \\ ${ }^{9}$ Division of Infectious Disease and Immunology, Department of Medicine, University of Massachusetts Medical School, \\ 55 Lake Avenue North, Worcester, MA 01655, USA \\ ${ }^{10}$ Departamento de Microbiologia, Imunologia e Parasitologia, Universidade Federal de Santa Catarina, \\ Campus Universitário da Trindade, 88040-900 Florianopolis, SC, Brazil
}

Correspondence should be addressed to Mauricio Martins Rodrigues; mrodrigues@unifesp.br

Received 26 March 2014; Accepted 25 May 2014; Published 26 June 2014

Academic Editor: Marcelo T. Bozza

Copyright (C) 2014 Adriano Fernando Araújo et al. This is an open access article distributed under the Creative Commons Attribution License, which permits unrestricted use, distribution, and reproduction in any medium, provided the original work is properly cited.

In earlier studies, we reported that a heterologous prime-boost regimen using recombinant plasmid DNA followed by replicationdefective adenovirus vector, both containing Trypanosoma cruzi genes encoding trans-sialidase (TS) and amastigote surface protein (ASP) 2, provided protective immunity against experimental infection with a reticulotropic strain of this human protozoan parasite. Herein, we tested the outcome of genetic vaccination of F1 (CB10XBALB/c) mice challenged with myotropic parasite strains (Brazil and Colombian). Initially, we determined that the coadministration during priming of a DNA plasmid containing the murine IL-12 gene improved the immune response and was essential for protective immunity elicited by the heterologous prime-boost regimen in susceptible male mice against acute lethal infections with these parasites. The prophylactic or therapeutic vaccination of resistant female mice led to a drastic reduction in the number of inflammatory infiltrates in cardiac and skeletal muscles during the chronic phase of infection with either strain. Analysis of the electrocardiographic parameters showed that prophylactic vaccination reduced the frequencies of sinus arrhythmia and atrioventricular block. Our results confirmed that prophylactic vaccination using the TS and ASP-2 genes benefits the host against acute and chronic pathologies caused by T. cruzi and should be further evaluated for the development of a veterinary or human vaccine against Chagas disease. 


\section{Introduction}

Chagas disease is an acute and chronic illness caused by Trypanosoma cruzi, an obligatory intracellular protozoan parasite that is endemic in the Americas. The disease currently affects millions of people who are chronically infected. Thousands of new cases are also estimated to occur every year $[1,2]$. Prophylactic measures aimed at eliminating transmission by the vector (kissing bugs) have been very successful in many countries [3]. Considering their success and the highly neglected state of Chagas disease research, vaccine development has often been considered a difficult and expensive strategy for disease control and eradication.

Despite this general consideration, recent theoretical studies have shown a divergent perspective on the problem, indicating that the development of a vaccine against Chagas disease would be cost effective even if the efficacy is not high and the transmission is low $[4,5]$. In moving toward the development of vaccines against Chagas disease, several laboratories have described a number of antigens and delivery systems capable of providing some degree of protective immunity against experimental infections. These systems include genetically attenuated parasites, recombinant protein in adjuvant systems, and genetically modified bacteria or viral vectors (reviewed in [6-12]). The antigens pursued for recombinant vaccines include $T$. cruzi transsialidase, cruzain (a cysteine proteinase), and the amastigote surface proteins 2, 3, 4, TcG1, TcG2, TcG4, TSA-1, and Tc24 (reviewed in [6-12]).

Our group in particular has been working for many years on the development of genetic vaccines against T. cruzi infection. We initially used the gene encoding the catalytic domain of the parasite trans-sialidase (TS, $[13,14]$ ). More recently, we have described studies using a heterologous prime-boost regimen consisting of priming with plasmid DNA followed by a booster injection with replication-defective recombinant human adenovirus type 5 . Both the prime and the boost contained the gene encoding the amastigote surface protein (ASP)-2 antigen of T. cruzi. This regimen successfully vaccinated highly susceptible $\mathrm{A} / \mathrm{Sn}$ and resistant $\mathrm{C} 57 \mathrm{BL} / 6$ mice against infection with the reticulotropic $\mathrm{Y}$ strain of $T$. cruzi [15-18]. Protective immunity was mediated by longlived $\mathrm{CD}^{+}$and $\mathrm{CD}^{+} \mathrm{T}$ Effector or effector memory cells $[15,19,20]$.

T. cruzi infection in mammalian hosts leads to diverse clinical manifestations. Among the most relevant factors influencing this diversity is the existence of biologically different parasite strains. T. cruzi intraspecific nomenclature was established in 2009, and the isolates and strains are assigned to one of six genetic groups or discrete typing units, named TcI to TcVI [21]. Among domestic transmission cycles, TcI occurs predominantly in northern South America, while TcII, $\mathrm{TcV}$, and TcVI are more often observed in the Southern Cone countries [22]. Considering this genetic variability, it is important that studies of vaccination or chemotherapy are conducted in different experimental models using distinct parasite strains. Because our previous studies of vaccination have been performed with the reticulotropic Y strain (TcII), it was our intention to extend these studies using experimental infections with two myotropic strains of the parasites belonging to TcI (Colombian) and TcII (Brazil).

\section{Materials and Methods}

2.1. Ethics Statement. This study was carried out in strict accordance with the recommendations in the Guide for the Care and Use of Laboratory Animals of the Brazilian National Council of Animal Experimentation (http://www.cobea.org .br/). The protocol was approved by the Committee on the Ethics of Animal Experiments of the Institutional Animal Care and Use Committee at the Federal University of Sao Paulo (Id \# CEP 0426/09).

2.2. Mice and Parasites. Female or male 5- to 8-week-old F1 $(\mathrm{CB} 10 \mathrm{XBALB} / \mathrm{c})$ mice were purchased from CEDEME (Federal University of São Paulo). Bloodstream trypomastigotes of the Colombian or Brazil strain of T. cruzi were obtained from mice infected 21-28 days earlier. The concentration of parasites was estimated and adjusted to $10^{4}$ parasites $/ \mathrm{mL}$. Each mouse was inoculated with $10^{3}$ trypomastigotes diluted in $0.1 \mathrm{~mL}$ PBS and administrated subcutaneously (s.c.) in the base of the tail.

2.3. Peptides. Synthetic peptides (Genscript, Piscataway, New Jersey) were higher than $90 \%$ pure. The immunodominant epitopes of ASP-2 or TS were represented by AA VNHRFTLV or IYNVGQSVI, respectively.

2.4. Genetic Vaccination. The plasmid (pWRG3169) containing coding sequences for the p35 and p40 subunits of murine (m) IL-12 was generated as earlier described [23]. Plasmids p154/13 (TS gene) or pIgSPclone9 (ASP-2 gene) were generated, grown, and purified as described earlier [13, 24]. Human replication deficient adenovirus type 5 expressing the ASP-2 gene (AdASP-2) or TS gene (AdTS) was generated and produced as described earlier [25] Control mice were immunized with pcDNA3 and human replication deficient adenovirus type 5 expressing $\beta$-galactosidase ( $\mathrm{Ad} \beta$-gal). F1 $(\mathrm{CB} 10 \mathrm{XBALB} / \mathrm{c})$ mice were immunized i.m. in each tibialis anterioris muscle with plasmid DNA. For priming, control mice received plasmid pcDNA3 $(300 \mu \mathrm{g})$, a second group was immunized with a mixture of pIgSPCl9 and p154/13 $(200 \mu \mathrm{g})$, and the third, a mixture of pIL12, pIgSPCl9, and p154/13 (300 $\mu \mathrm{g})$. Twenty-one days later, these mice received in these same spots $100 \mu \mathrm{L}$ of viral suspension containing a total of $2 \times 10^{8}$ plaque forming units ( $\mathrm{pfu}$ ) of rec. adenovirus. For boosting, control mice received adenovirus Ad $\beta$ gal; other mouse groups were immunized with a mixture of rec. adenovirus AdASP-2 and Ad-TS. Immunological assays were performed 14 days after viral inoculation.

Therapeutic vaccination was performed as follows. F1 $(\mathrm{CB} 10 \mathrm{XBALB} / \mathrm{c})$ female mice were challenged s.c. with 1,000 trypomastigotes of the indicated parasite strain. Thirty days later, control mice received a mixture of plasmid pcDNA3 and of pIL12 $(300 \mu \mathrm{g})$ and second mice group was immunized with a mixture of pIL12pIgSPCl9 and p154/13 (300 $\mu \mathrm{g})$. Twenty days later, these mice received in these same spots 
$100 \mu \mathrm{L}$ of viral suspension containing a total of $2 \times 10^{8} \mathrm{pfu}$ of rec. adenovirus. For boosting, control mice received adenovirus $\mathrm{Ad} \beta$ gal and the other mice were immunized with a mixture of rec. adenovirus AdASP-2 and Ad-TS.

2.5. Immunological Assays. For the surface intracellular expression of cytokines (IFN $\gamma$ and TNF, ICS) or translocation of CD107a to the membrane, splenocytes collected from immune mice were treated with ACK buffer. ICS and surface mobilization of CD107a were evaluated after in vitro culture of splenocytes in the presence or absence of the antigenic stimulus. Cells were washed 3 times in plain RPMI and resuspended in cell culture medium consisting of RPMI 1640 medium, $\mathrm{pH} 7.4$, supplemented with $10 \mathrm{mM}$ Hepes, $0.2 \%$ sodium bicarbonate, $59 \mathrm{mg} / \mathrm{L}$ of penicillin, $133 \mathrm{mg} / \mathrm{L}$ of streptomycin, and 10\% Hyclone fetal bovine sera (Hyclone, Logan, Utah). The viability of the cells was evaluated using $0.2 \%$ trypan blue exclusion dye to discriminate between live and dead cells. Cell concentration was adjusted to $5 \times 10^{6}$ cells/mL in cell culture medium containing FITC-labeled anti-CD107a $(2 \mu \mathrm{g} / \mathrm{mL})$, anti-CD28 $(2 \mu \mathrm{g} / \mathrm{mL})$, BdGolgiPlug, and monensin $(5 \mu \mathrm{g} / \mathrm{mL})$. In part of the cultures, a final concentration of $10 \mu \mathrm{M}$ of the VNHRFTLV or IYNVGQSVI peptides was added. The cells were cultivated in flat-bottom 96-well plates (Corning) in a final volume of $200 \mu \mathrm{L}$ in duplicate, at $37^{\circ} \mathrm{C}$ in a humid environment containing $5 \%$ $\mathrm{CO}_{2}$. After $12 \mathrm{~h}$ incubation, cells were stained for surface markers with PerCP-labeled anti-CD8, on ice for $20 \mathrm{~min}$. To detect IFN $\gamma$ and TNF by intracellular staining, cells were then washed twice in buffer containing PBS, 0.5\% BSA, and $2 \mathrm{mM}$ EDTA, fixed and permeabilized with BD perm/wash buffer. After being washed twice with $\mathrm{BD}$ perm/wash buffer, cells were stained for intracellular markers using APClabeled anti-IFN $\gamma$ (Clone XMG1.2) and PE-labeled anti-TNF (clone MP6-XT22). Finally, cells were washed twice with BD perm/wash buffer and fixed in 1\% PBS-paraformaldehyde. At least 300,000 cells were acquired on a BD FacsCanto flow cytometer and then analyzed with FlowJo.

2.6. Electrocardiogram (ECG). Mice were i.p. tranquilized with diazepan $(20 \mathrm{mg} / \mathrm{kg})$ and transducers were carefully placed under the skin in accordance with chosen preferential derivation (DII). Traces were recorded using a digital system (Power Lab 2/20) connected to a bioamplifier in $2 \mathrm{mV}$ for $1 \mathrm{~s}$ (PanLab Instruments). Filters were standardized between 0.1 and $100 \mathrm{~Hz}$ and traces were analyzed using the Scope software for Windows V3.6.10 (PanLab Instruments). We measured heart rate (beats per minute-bpm), duration of the PR, QRS, and QT intervals, and P wave in ms (millisecond) on $222 \mathrm{dpi}$. The relationship between the QT interval and RR interval was individually assessed to obtain physiologically relevant values for the heart rate-corrected QT interval (QTc) through Bazzet's formula.

2.7. Morphometric Analyses. Analyses were performed essentially as described in [26]. Briefly, heart sections were analyzed by light microscopy after paraffin embedding, followed by standard hematoxylin and eosin staining. Inflammatory cells infiltrating heart tissue were counted using a digital morphometric evaluation system. Images were digitized using a color digital video camera (CoolSnap, Photometrics, Montreal, QC, Canada) adapted to a BX41 microscope (Olympus, Tokyo, Japan). Morphometric analyses were performed using the software Image-Pro Plus v.7.0 (Media Cybernetics, San Diego, CA, USA). The inflammatory cells were counted in 10 fields $(\times 400$ view $) /$ heart. All of the analyses were performed in a blinded fashion.

2.8. Statistical Analysis. For the purpose of comparing the different mouse groups, we used the statistical analyses suggested by [27]. The values were compared using One Way ANOVA followed by Tukey's HSD tests or Fisher exact probability test (http://faculty.vassar.edu/lowry/VassarStats .html/). The Logrank test was used to compare mouse survival rates after challenge with T. cruzi (http://bioinf.wehi.edu .au/software/russell/logrank/). The differences were considered significant when the $P$ value was $<0.05$.

\section{Results}

3.1. Addition of pIL-12 during Priming Improved the Immune Response Mediated by $\mathrm{CD}^{+} \mathrm{T}$ Cells and Increased Protective Immunity against Acute Infection. A previous study has reported that the coadministration of plasmid DNA expressing IL-12 during priming improves the efficacy of a heterologous prime-boost vaccination regimen, as estimated by protective immunity against SIV infection [28]. We, therefore, decided to determine whether this strategy could also improve the immune response and protective immunity against T. cruzi infection in the mouse model. Mice were immunized with the following: (i) pcDNA3 followed by a booster injection of Ad $\beta$ gal (G1, control); (ii) p154/13 and pIgSPCl9 followed by a booster injection of AdASP-2 and AdTS (G2); (iii) pIL-12, p154/13 and pIgSPCl9 followed by a booster injection of AdASP-2 and AdTS (G3).

To compare the different mouse groups, we stained $\mathrm{CD}^{+}$spleen cells following in vitro peptide stimulation for the surface mobilization of CD107a, a marker for $\mathrm{T}$ cell degranulation, and intracellular effector cytokines (IFN $\gamma$ and TNF, ICS). Figure 1(a) depicts examples of the frequency estimates of peptide-specific $\mathrm{CD}^{+}$spleen cells that mobilized $\mathrm{CD} 107 \mathrm{a}$ to their surface and expressed IFN $\gamma$. The frequencies of $\mathrm{CD}^{+}$cells that mobilized CD107a to the cell surface and expressed IFN $\gamma$ were higher in G3. Control mice (G1) had a negligible number of specific $\mathrm{CD} 8^{+} \mathrm{CD} 107 \mathrm{a}^{+} \mathrm{IFN} \gamma^{+}$cells. These frequencies were dependent on the presence of peptide in culture because the frequency of $\mathrm{CD}^{+} \mathrm{CD} 107 \mathrm{a}^{+} \mathrm{IFN} \gamma^{+}$ cells was very small in the absence of peptide in all groups.

We made a similar observation when we estimated the frequencies of splenic peptide-specific CD8 cells that expressed IFN $\gamma$ or IFN $\gamma$ and TNF. These frequencies were higher in G3 mice (Figure 1(b)). As described above, control mice (G1) had a negligible number of specific $\mathrm{CD} 8^{+} \mathrm{IFN} \gamma^{+}$ or $\mathrm{CD}^{+} \mathrm{IFN} \gamma^{+} \mathrm{TNF}^{+}$cells. The numerical differences and the statistical significances are depicted in Figures 1(c)1(f). As shown in Figures 1(d) and 1(f), following peptide 


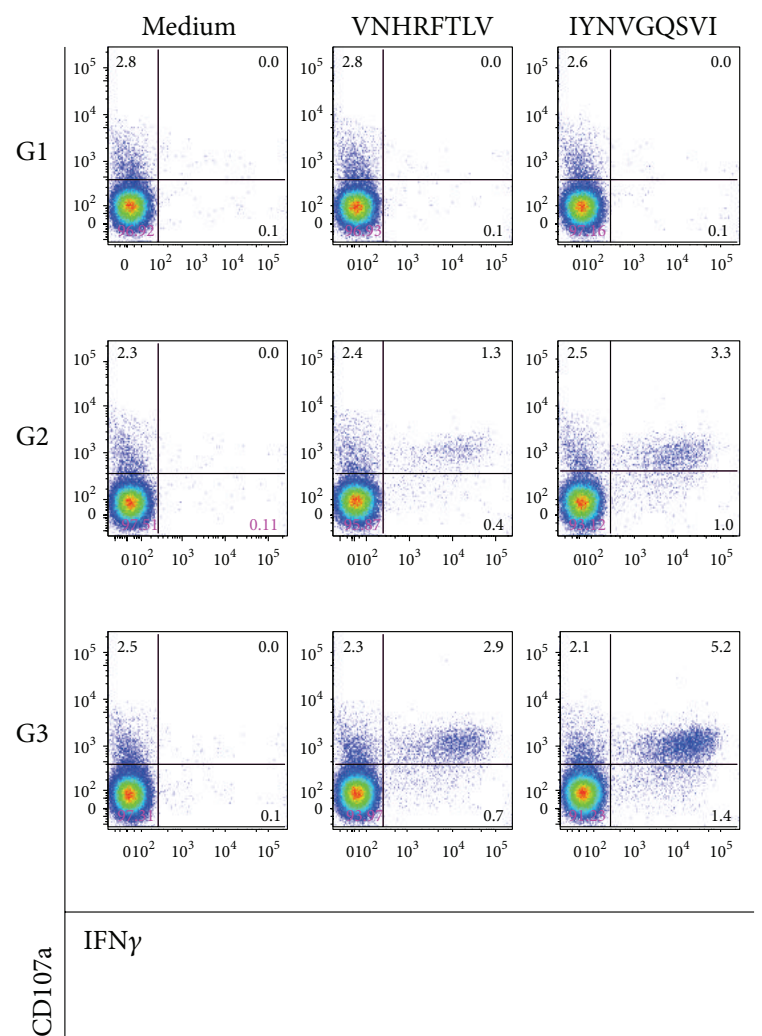

(a)

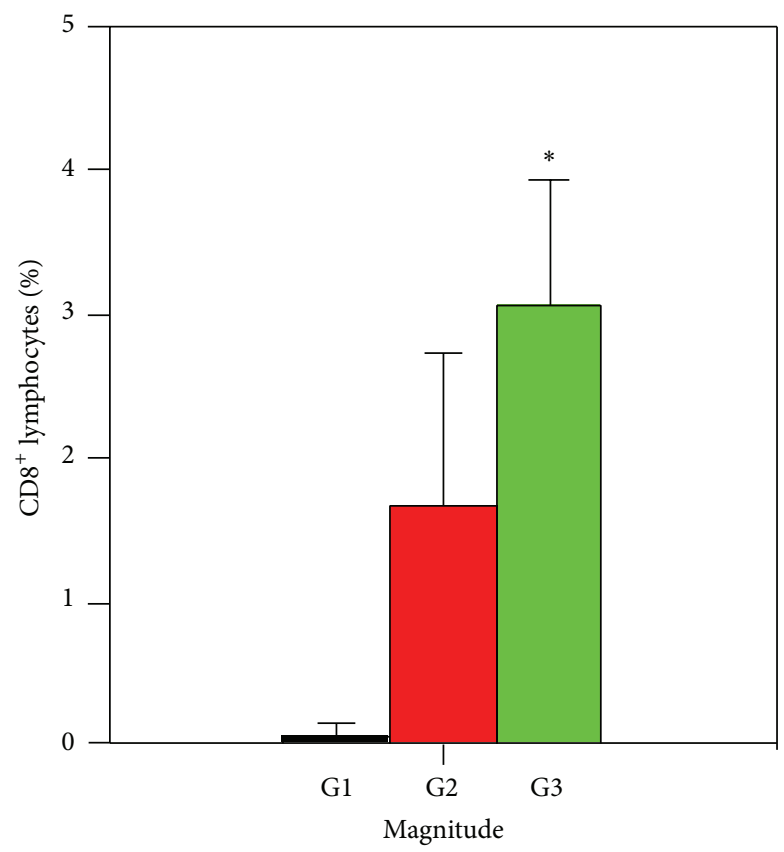

Priming

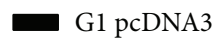

G2 p154/13+pIgSPCl.9

$\square$ G3 pIL12+p154/13+pIgSPCl.9

Boosting

Ad $\beta$-gal

AdTS+AdASP2

AdTS+AdASP2

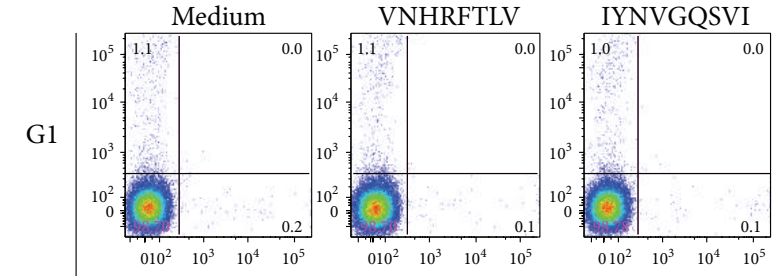

G2

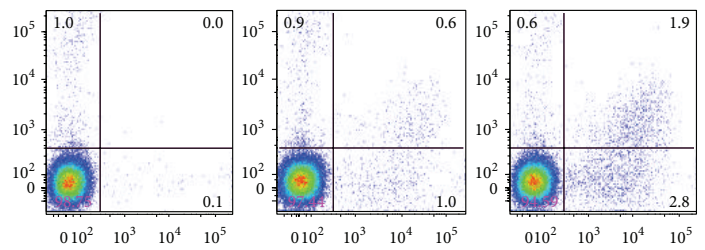

G3

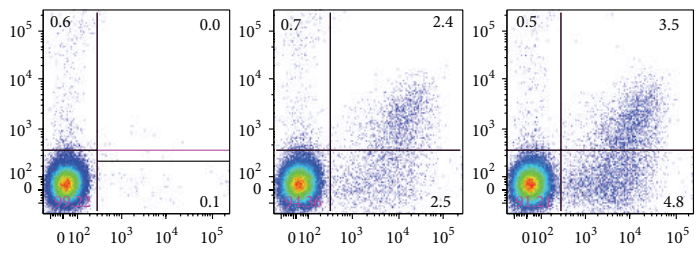

IFN $\gamma$

岁

(b)

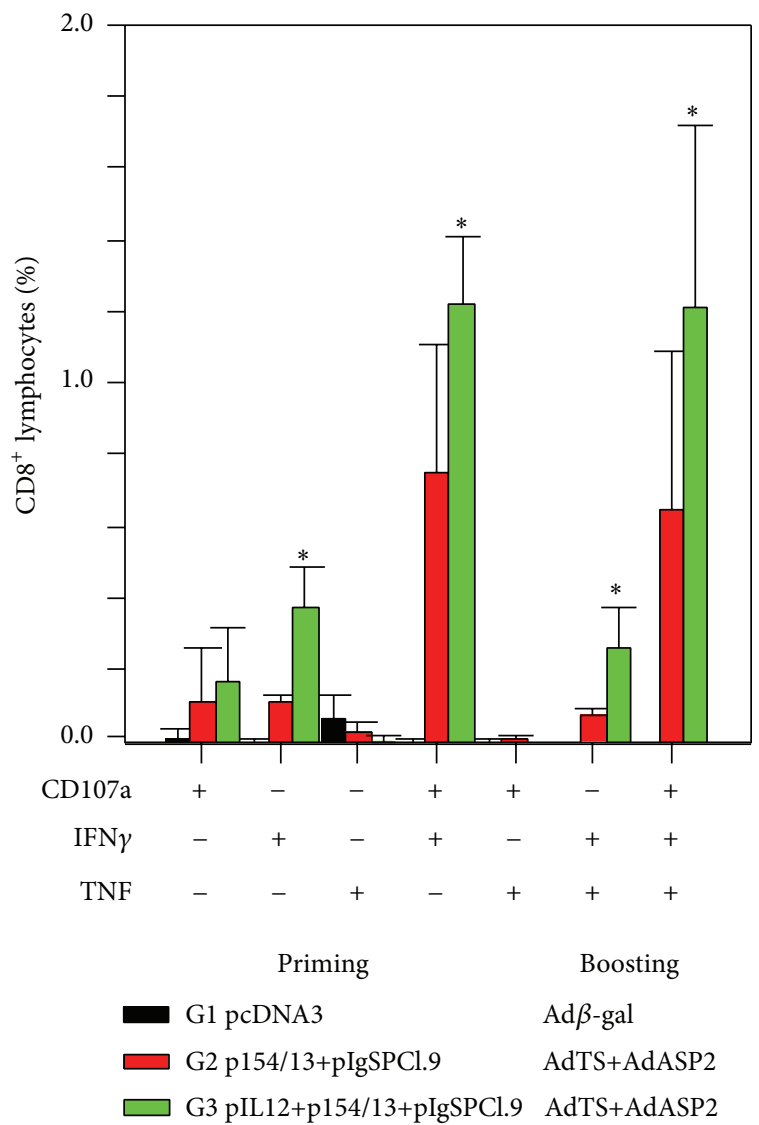

(c)

(d)

Figure 1: Continued. 


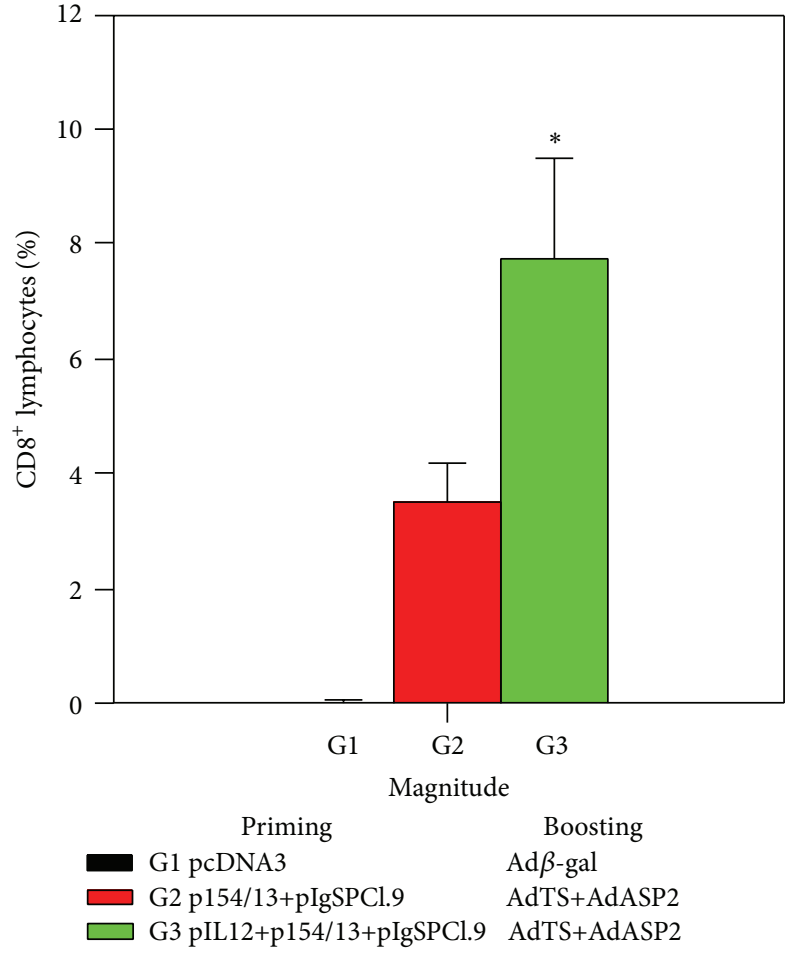

(e)

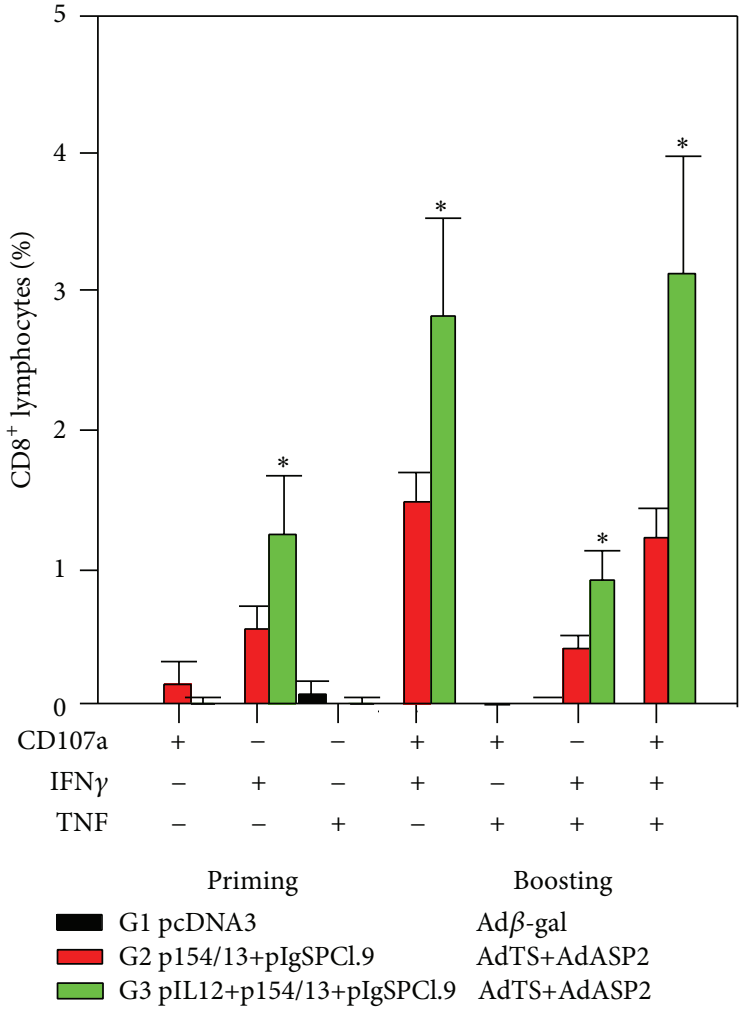

(f)

FIGURE 1: Frequencies of specific cytokine-secreting splenic $\mathrm{CD} 8^{+} \mathrm{T}$ cells in mice vaccinated with the heterologous prime-boost vaccination regimen. F1 (CB10XBALB/c) mice were immunized i.m. in each tibialis anterior muscle with plasmid DNA. For priming, G1 received control plasmid pcDNA3 $(300 \mu \mathrm{g}), \mathrm{G} 2$ was immunized with a mixture of pIgSPCl9 and p154/13 (200 $\mu \mathrm{g})$, and G3 received a mixture of pIL-12, pIgSPC19, and p154/13 $(300 \mu \mathrm{g})$. Twenty-one days later, these mice received, in these same spots, $100 \mu \mathrm{L}$ of a viral suspension containing a total of $2 \times 10^{8}$ pfu of rec. adenovirus. For boosting, G1 received control adenovirus Ad $\beta$ gal, and G2 and G3 were immunized with a mixture of rec. adenovirus AdASP-2 and Ad-TS. Immunological assays were performed 14 days after viral inoculation. Spleen cells were restimulated in vitro in the presence or absence of the peptides VNHRFTLV or IYNVGQSVI, anti-CD107a, anti-CD28, BdGolgiPlug, and monensin. After 12 h, the cells were stained with anti-CD8, anti-IFN $\gamma$, and anti-TNF. (a) The histograms show FACS analysis of CD8+ cells. The numbers represent the frequencies of cells stained for CD107a and/or IFN $\gamma$. The results are a representative of 4 mice per group (Median). (b) Frequencies of CD8+ cells stained for IFN $\gamma$ and/or TNF. The results are a representative of 4 mice per group (Median). (c) Total frequencies of CD8+ cells specific for the peptide VNHRFTLV and stained for CD107a or IFN $\gamma$ or TNF. The results are representative of 4 mice per group (Mean \pm SD). (d) Frequencies of CD8+ cells specific for the peptide VNHRFTLV and stained for each marker (CD107a, IFN $\gamma$, or TNF). The results are representative of 4 mice per group (Mean \pm SD). (e) Same as in (c) for CD8+ cells specific for the peptide IYNVGQSVI. The results are representative of 4 mice per group (Mean $\pm \mathrm{SD}$ ). (f) Same as in (d) for CD8+ cells specific for the peptide IYNVGQSVI. All three groups were compared statistically by one-way ANOVA followed by Tukey HSD (c-e). The values of G2 and G3 mice were always higher than those of G1 mice $(P<0.01$ in all cases). Asterisks denote that the values of G3 mice were higher than those of G2 mice $(P<0.05)$. The results are representative of three independent experiments.

stimulation in vitro, most of the $\mathrm{CD}^{+}$cells were either $\mathrm{CD} 107 \mathrm{a}^{+} \mathrm{IFN} \gamma^{+} \mathrm{TNF}^{+}$or $\mathrm{CD} 107 \mathrm{a}^{+} \mathrm{IFN} \gamma^{+}$.

To determine whether this improvement in the frequencies of specific $\mathrm{CD}^{+} \mathrm{T}$ cells would impact protective immunity, we vaccinated susceptible male mice and challenged them with trypomastigotes of either the Brazil or Colombian strain. As shown in Figures 2(a) and 2(c), mice vaccinated with the TS and ASP-2 genes (G2 and G3) presented a statistically significant reduction in peak parasitemia. A comparison between these two groups also showed that the parasitemia in G3 was significantly lower than that in G2. Not only did mice from G3 display lower parasitemia, but vaccination also significantly reduced mouse mortality
(Figures 2(b) and 2(d)). While all G3 mice survived the experimental challenge, most control (G1) and G2 mice died after challenge with the Brazil or Colombian parasite strain. Based on these results, we concluded that the use of pIL12 for priming significantly improved the immune response and the protective immunity against acute infection with the myotropic Brazil and Colombian strains.

\subsection{Impact of Genetic Vaccination against Chronic Infection.} To evaluate the impact of genetic vaccination on the chronic symptoms of the experimental infection, resistant female mice were treated according to the following protocols: (i) naïve (G1); (ii) pIL-12 and pcDNA3 followed by a booster 


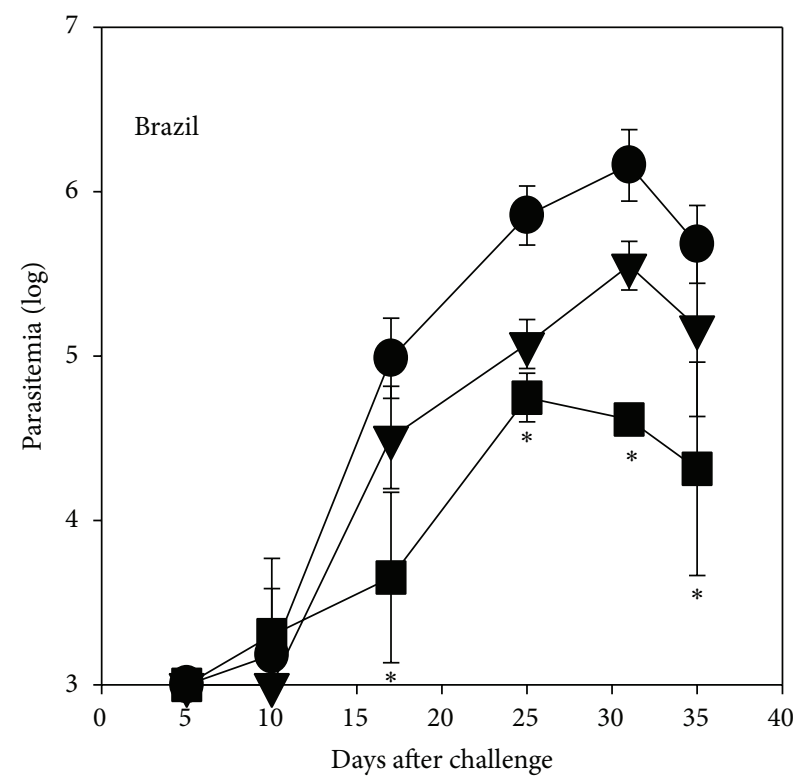

(a)

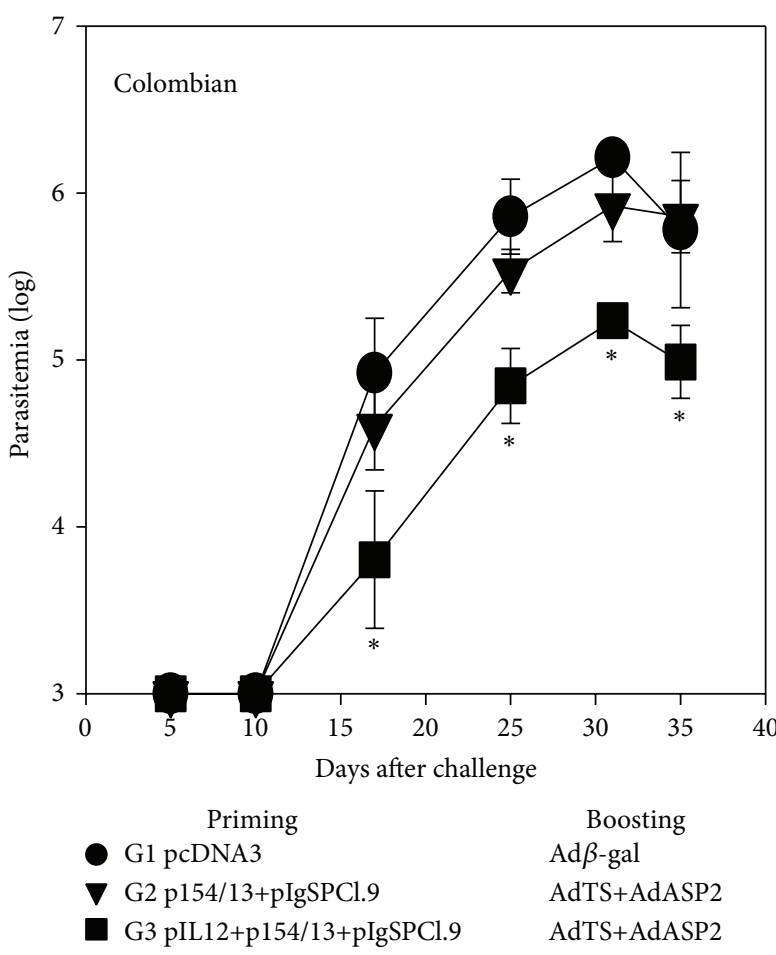

(c)

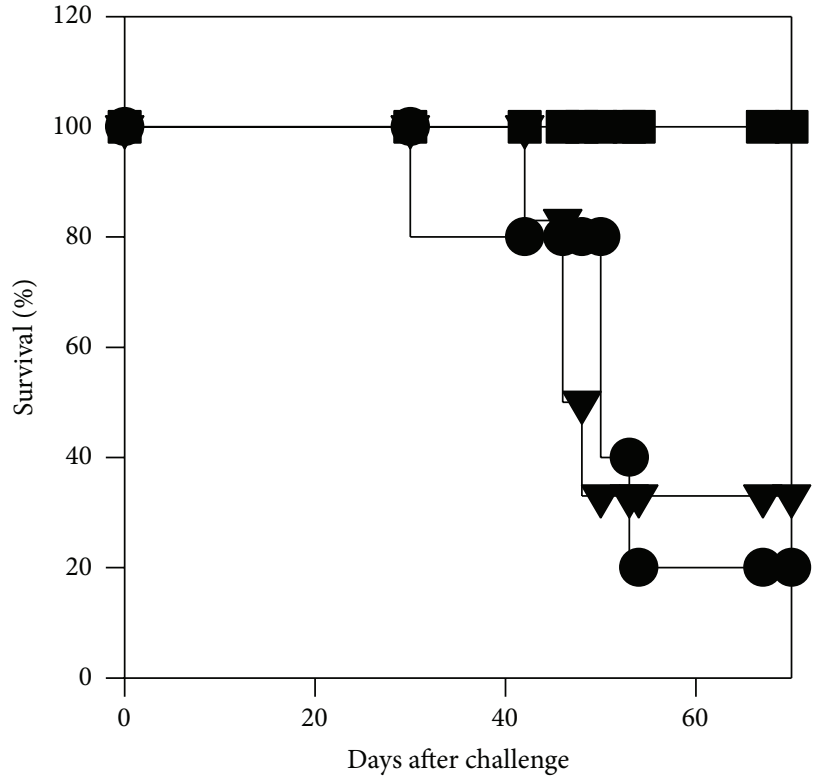

(b)

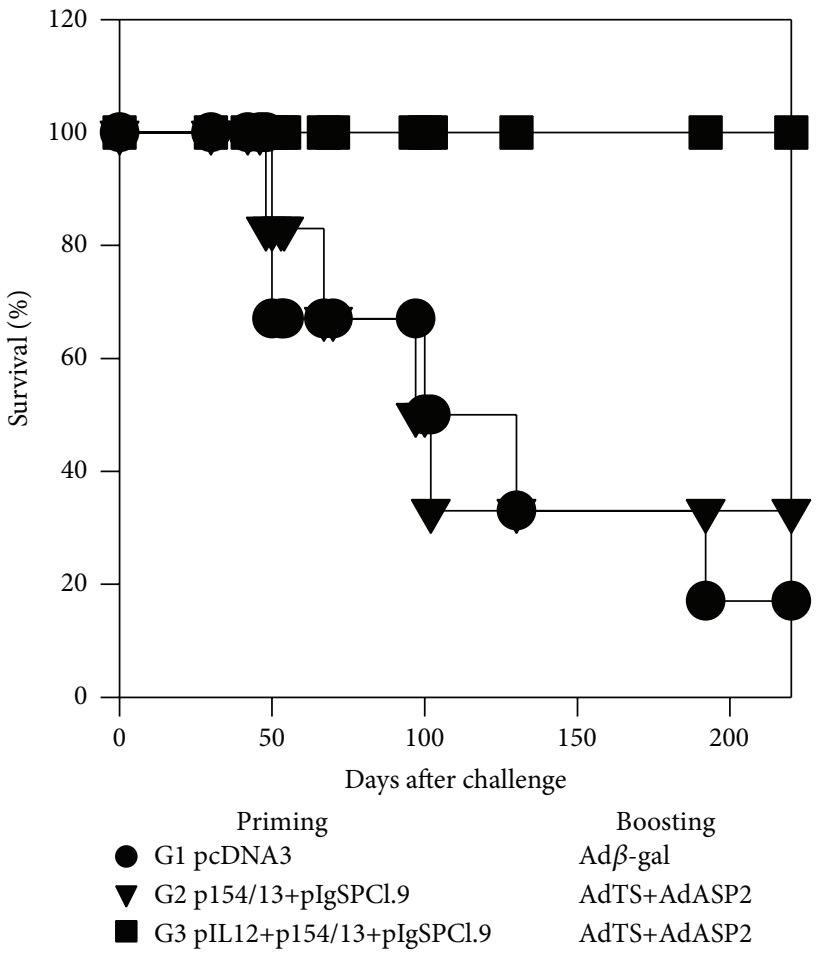

(d)

FIGURE 2: The protective immunity elicited by heterologous prime-boost vaccination in susceptible mice. F1 (CB10XBALB/c) male mice were immunized i.m. exactly as described in the legend of Figure 1. Fourteen days later, mice were challenged s.c. with 1,000 trypomastigotes of the indicated parasite strain. (a) Mean parasitemia \pm SD of each mouse group $(n=6)$ challenged with parasites of the Brazil strain. The values of G2 and G3 mice at days 21, 25 and 35 were lower than those of G1 mice $(P<0.01$ in all cases, one-way ANOVA, Tukey HSD). Asterisks denote that the values of G3 mice were lower than those of G2 mice $(P<0.05)$; (b) The Kaplan-Meier survival curves of the different groups were compared, and the results showed that G3 survived significantly longer $(P<0.01)$ than the two other groups; (c) Mean parasitemia \pm SD of each mouse group $(n=6)$ challenged with parasites of the Colombian strain. The values of G2 and G3 mice at days 25 and 31 were lower than those of G1 mice ( $P<0.01$ in all cases). Asterisks denote that the values of G3 mice were lower than those of the G2 mice $(P<0.05)$; $(\mathrm{d})$ The Kaplan-Meier survival curves of the different groups were compared, and the results showed that G3 survived significantly longer $(P<0.01)$ than the two other groups. The results were obtained from one of two independent experiments. 
TABLE 1: Summary of the ECG records.

\begin{tabular}{|c|c|c|c|c|c|c|c|}
\hline \multirow{2}{*}{$\begin{array}{l}\text { Days after } \\
\text { challenge }\end{array}$} & \multirow{2}{*}{ Strain } & \multicolumn{3}{|c|}{ Sinus arrhythmia mouse groups } & \multicolumn{3}{|c|}{$P$ values } \\
\hline & & G1 & G2 & G3 & $\mathrm{G} 1 \times \mathrm{G} 2$ & $\mathrm{G} 1 \times \mathrm{G} 3$ & $\mathrm{G} 2 \times \mathrm{G} 3$ \\
\hline 80 & Brazil & $0 / 6$ & $0 / 6$ & $0 / 6$ & NS & NS & NS \\
\hline 150 & Brazil & $0 / 6$ & $19 / 6$ & $0 / 6$ & 0.001 & NS & 0.001 \\
\hline 240 & Brazil & $0 / 6$ & $20 / 6$ & $3 / 6$ & 0.001 & NS & 0.026 \\
\hline 80 & Colombian & $0 / 6$ & $0 / 6$ & $0 / 5$ & NS & NS & NS \\
\hline 150 & Colombian & $0 / 6$ & $1 / 6$ & $1 / 5$ & NS & NS & NS \\
\hline 240 & Colombian & $0 / 6$ & $9 / 6$ & $1 / 5$ & 0.017 & NS & 0.093 \\
\hline \multirow{2}{*}{$\begin{array}{l}\text { Days after } \\
\text { challenge }\end{array}$} & \multirow{2}{*}{ Strain } & \multicolumn{3}{|c|}{ Atrioventricular block } & \multicolumn{3}{|c|}{$P$ values } \\
\hline & & G1 & G2 & G3 & $\mathrm{G} 1 \times \mathrm{G} 2$ & $\mathrm{G} 1 \times \mathrm{G} 3$ & $\mathrm{G} 2 \times \mathrm{G} 3$ \\
\hline 80 & Brazil & $0 / 6$ & $0 / 6$ & $0 / 6$ & NS & NS & NS \\
\hline 150 & Brazil & $0 / 6$ & $4 / 6$ & $2 / 6$ & 0.03 & NS & NS \\
\hline 240 & Brazil & $0 / 6$ & $59 / 6$ & $7 / 6$ & 0.001 & 0.004 & 0.003 \\
\hline 80 & Colombian & $0 / 6$ & $19 / 6$ & $0 / 5$ & 0.001 & NS & NS \\
\hline 150 & Colombian & $0 / 6$ & $14 / 6$ & $6 / 5$ & 0.001 & 0.002 & NS \\
\hline 240 & Colombian & $0 / 6$ & $39 / 6$ & $10 / 5$ & 0.001 & 0.002 & NS \\
\hline
\end{tabular}

ECG record of mice genetically vaccinated and challenged as described in the legend of Figure 5(a). Values represent the number of episodes (sinus arrhythmia or atrioventricular block) recorded during one minute per total of mice analyzed and were compared by Fisher exact probability test.

injection of Ad $\beta$ gal (G2, control); (iii) pIL-12, p154/13 and pIgSPCl9 followed by a booster injection of AdASP-2 and AdTS (G3).

G2 and G3 mice were subsequently challenged with parasites of either the Brazil or the Colombian strain, as depicted in Figure 3(a). We estimated the level of parasitemia for each mouse group. G3 mice presented a lower peak parasitemia at day $27(P=0.02)$ after infection with parasites of the Brazil strain (Figure 3(b)). In the case of mice challenged with parasites of the Colombian strain, there was a statistically significant reduction in the levels of parasitemia at days $13,20,24,28$, and $31(P<0.05$ in all cases, Figure $3(\mathrm{c}))$.

Individual ECGs were evaluated at days 80, 150, and 240 following infection. As shown in Table 1, the primary abnormalities we detected were sinus arrhythmia and atrioventricular block. Significantly lower frequencies of sinus arrhythmia were observed in G3 mice when compared with G2 mice following infection with the Brazil or Colombian strains. These differences were observed at later days (150 or 240 days) following challenge. Similarly, significantly lower frequencies of atrioventricular block were observed in G3 mice when compared with G2 mice following infection with parasites of the Brazil strain. In the case of mice challenged with parasites of the Colombian strain, the differences were smaller and not statistically significant.

At day 240 after challenge, the mice were euthanized, and morphometric analyses of the heart and skeletal muscle were performed. The number of inflammatory cells within the skeletal muscle, but not the heart, of G3 mice challenged with parasites of the Brazil strain was significantly lower (Figure 4(b)). In G3 mice challenged with parasites of the Colombian strain, we found significantly lower numbers of inflammatory cells within the skeletal muscle and heart when compared to G2 mice (Figure 4(c)).

We then evaluated the impact of therapeutic genetic vaccination on the chronic symptoms of experimental infection. Resistant female mice were infected and then treated according to the protocols described in Figures 5(a) and 6(a). Mice received the following treatments: (i) pIL-12 and pcDNA3 followed by a booster injection of Ad $\beta$ gal (G2, control); (ii) pIL-12, p154/13 and pIgSPCl9 followed by a booster injection of AdASP-2 and AdTS (G3).

The estimation of parasitemia until day 50 did not reveal any difference between G2 or G3 mice infected with parasites of the Brazil or Colombian strains (Figures 5(b) and 5(c), resp.). We concluded that the plasmid administration at day 30 after challenge did not elicit immunity that could reduce the ongoing parasitemia. Individual ECGs were evaluated at days $90,120,150$, and 180 following infection. As shown in Table 2, we detected differences in the frequencies of sinus arrhythmia, but not atrioventricular block, in G3 mice when compared with G2 mice following infection with the Brazil strain of T. cruzi. However, this difference was observed only on days 90 and 120. Later (150 and 180 days), G3 mice also developed sinus arrhythmia. G3 mice infected with parasites of the Colombian strain had significantly lower frequencies of sinus arrhythmia at days 120 and 180, when G2 mice developed a significant number of events. However, the occurrence of atrioventricular block in G3 mice was similar to that in G2. At day 180 after challenge, the mice were euthanized, and morphometric analyses of the heart and skeletal muscle were performed. The numbers of inflammatory cells within the skeletal muscle and heart of G3 mice challenged with parasites of the Brazil or Colombian strains were significantly lower than the frequencies in the tissues of G2 mice (Figures 6(b) and 6(c), resp.).

\section{Discussion}

The present study evaluated the outcome of experimental infection with two myotropic T. cruzi strains in F1 $(\mathrm{CB} 10 \mathrm{XBALB} / \mathrm{c})$ mice genetically vaccinated with TS and ASP-2 following a heterologous DNA prime-adenovirus boost regimen. Prophylactic vaccination reduced the acute 


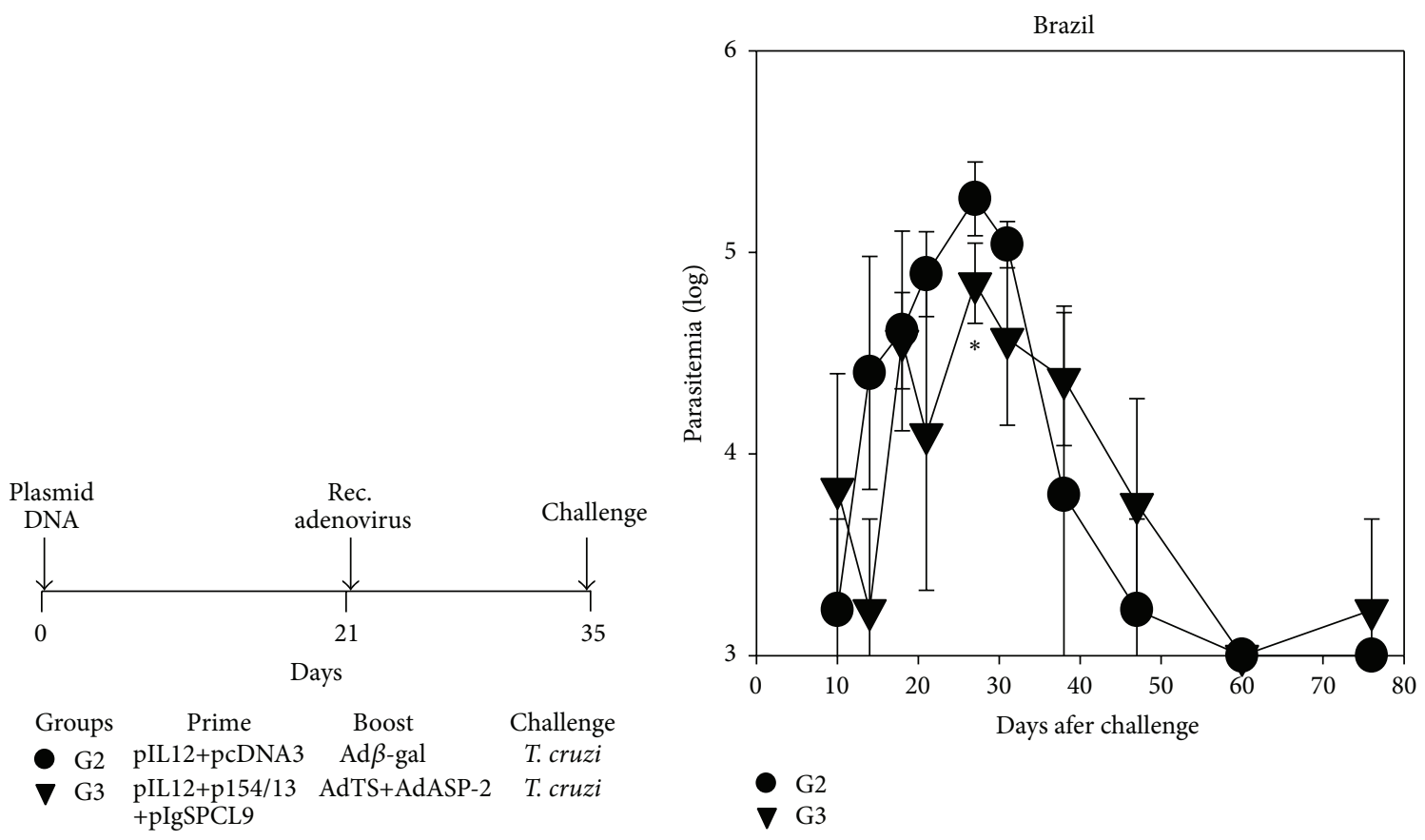

(a)

(b)

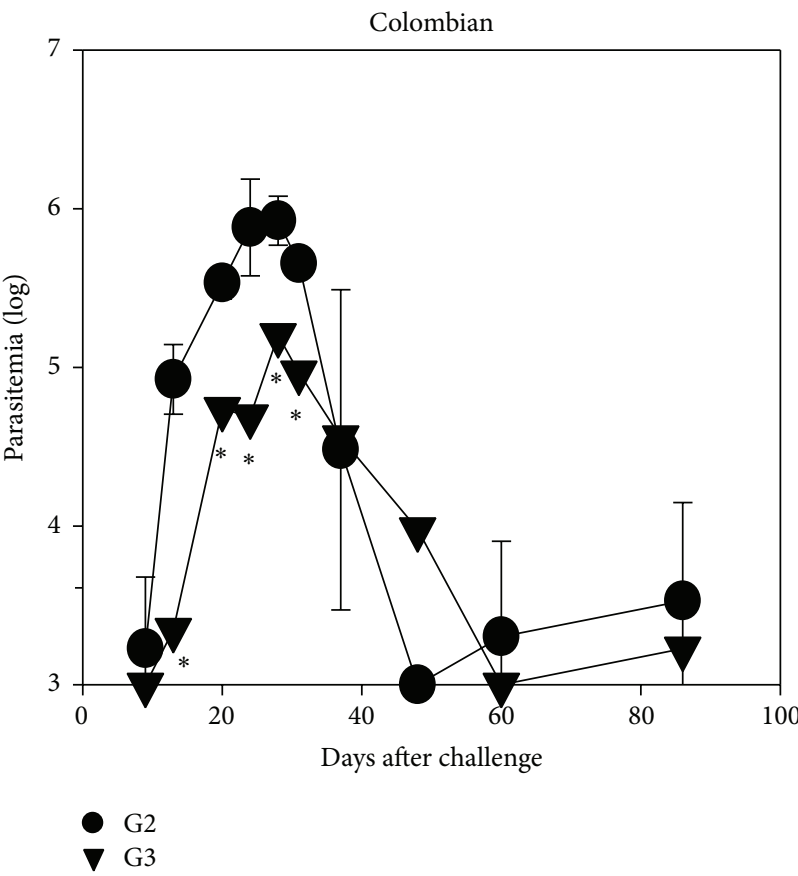

(c)

FIGURE 3: The protective immunity elicited by heterologous prime-boost vaccination in resistant mice. (a) F1 (CB10XBALB/c) female mice were immunized i.m. as depicted. For priming, G2 mice received a mixture of control plasmid pcDNA3 and of pIL-12 (300 $\mu \mathrm{g})$, and G3 mice were immunized with a mixture of pIL-12, pIgSPCl9 and p154/13 $(300 \mu \mathrm{g})$. Twenty-one days later, these mice received, in these same spots, $100 \mu \mathrm{L}$ of a viral suspension containing a total of $2 \times 10^{8} \mathrm{pfu}$ of rec. adenovirus. For boosting, G2 mice received control adenovirus Ad $\beta$ gal, and G3 mice were immunized with a mixture of rec. adenovirus AdASP-2 and Ad-TS. Fourteen days later, mice were challenged s.c. with 1,000 trypomastigotes of the indicated parasite strain. (b) Mean parasitemia \pm SD of each mouse group $(n=6)$ challenged with parasites of the Brazil strain. Asterisk denotes that at day 37, the values of G3 mice were lower than those of G2 mice $(P<0.05$, one-way ANOVA, Tukey HSD); (c) Mean parasitemia \pm SD of each mouse group $(n=6)$ challenged with parasites of the Colombian strain. Asterisks denote that at days 13 to 31 , the values of G3 mice were lower than those of G2 mice $(P<0.05)$. 


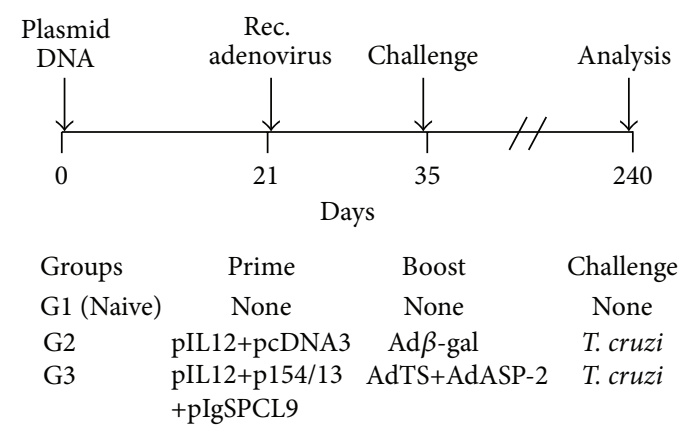

(a)

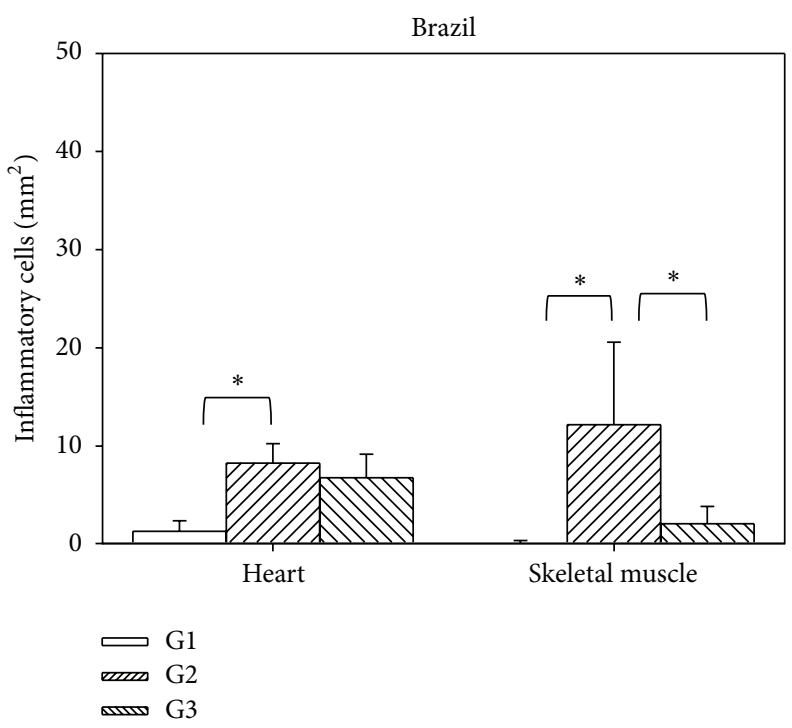

(b)

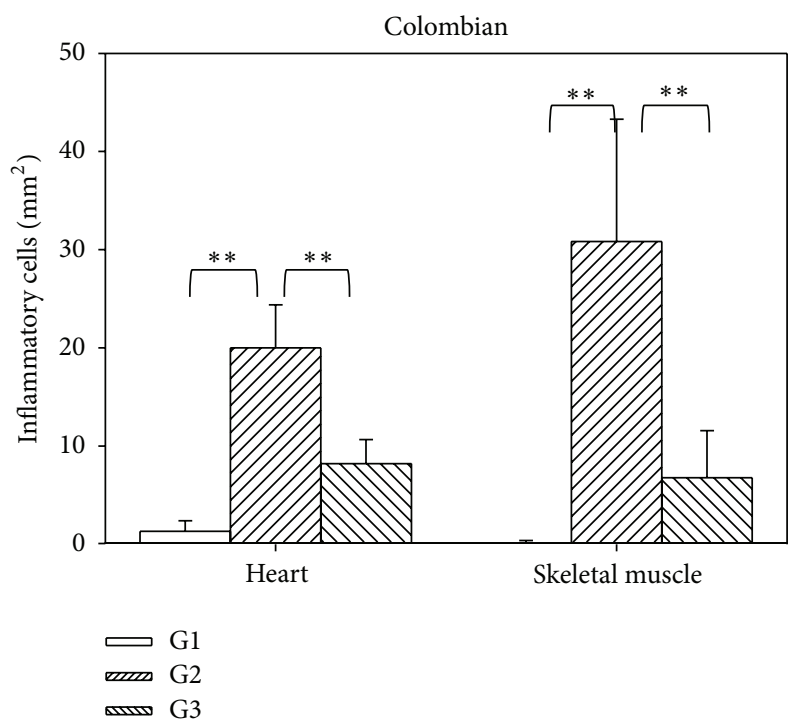

(c)

FIGURE 4: Frequencies of inflammatory cells in the hearts and skeletal muscles of resistant mice vaccinated by the heterologous prime-boost regimen. (a) F1 (CB10XBALB/c) female mice were immunized i.m., as depicted. Details on the dose are shown in Figure 3(a). (b) At 240 days, heart and skeletal muscle sections of mice challenged with the Brazil strain were stained with hematoxylin and eosin, and the number of inflammatory cells was quantified. Bars represent the mean of 6 mice/group \pm SD. Asterisks denote that there was a significant difference between the indicated groups $\left({ }^{*} P<0.05\right.$ or ${ }^{* *} P<0.01$ ). (c) The same as above, except that the mice were challenged with parasites of the Colombian strain. Bars represent the mean of 5 mice/group \pm SD.

phase symptoms, as estimated by parasitemia and mortality. In addition, ECG analysis demonstrated that prophylactic vaccination also reduced some of the chronic phase signs. These results essentially confirm and extend our previous observations in mice challenged with a reticulotropic T. cruzi strain [15-20].

In contrast to prophylactic vaccination, the therapeutic use of our vaccine had a much lower impact on the chronic phase signs evaluated by ECG. The treatment reduced sinus arrhythmia earlier in mice challenged with the Brazil strain. Additionally, most mice challenged with the Colombian strain never developed episodes of sinus arrhythmia. Despite this observation, no differences were detected in the frequencies of episodes of atrioventricular block. It is important to highlight that these ECG alterations occurred in mice with a reduced number of inflammatory cells in their heart. This dichotomy most likely reflects the successful control by vaccination of the inflammatory reactions later during 


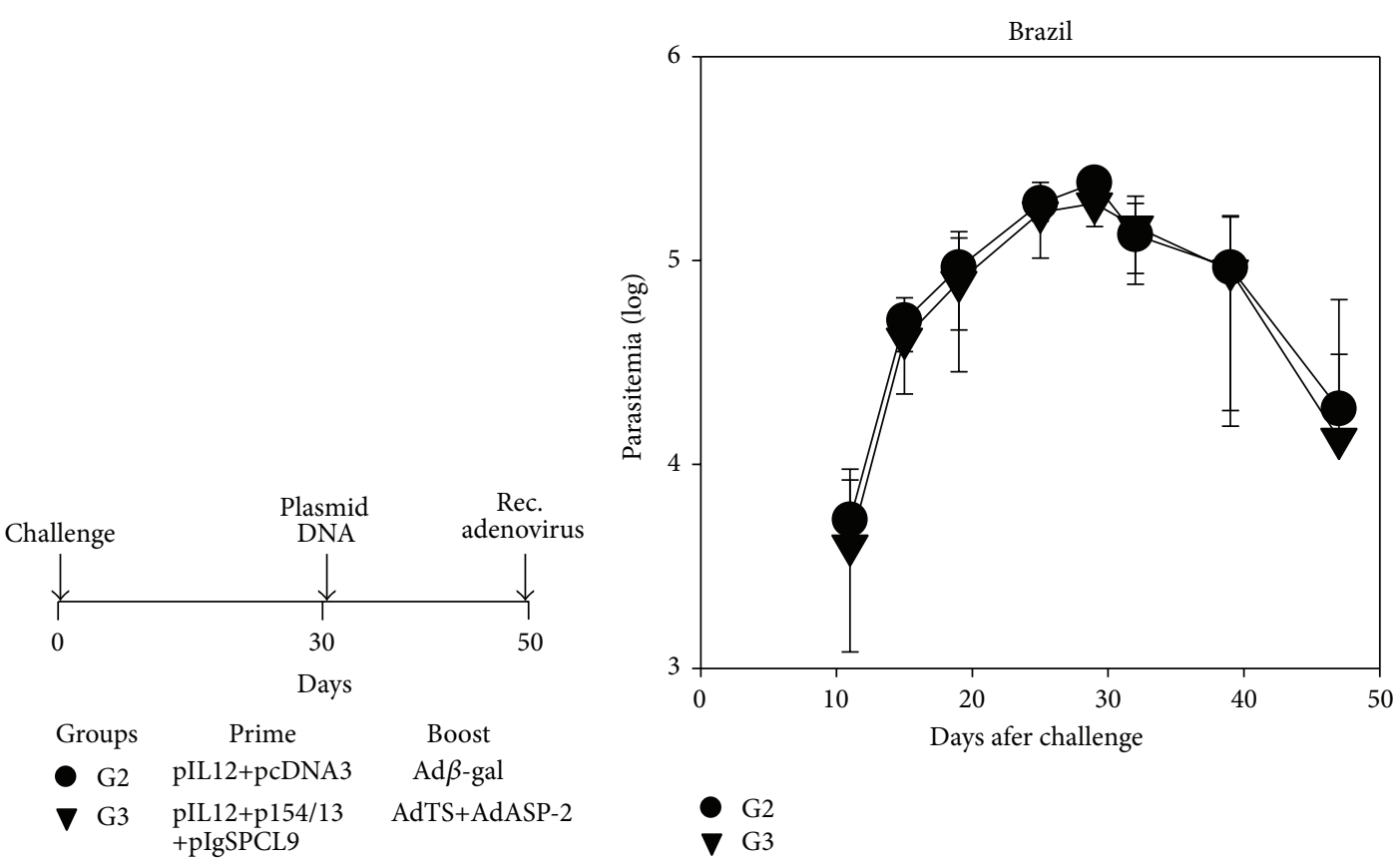

(a)

(b)

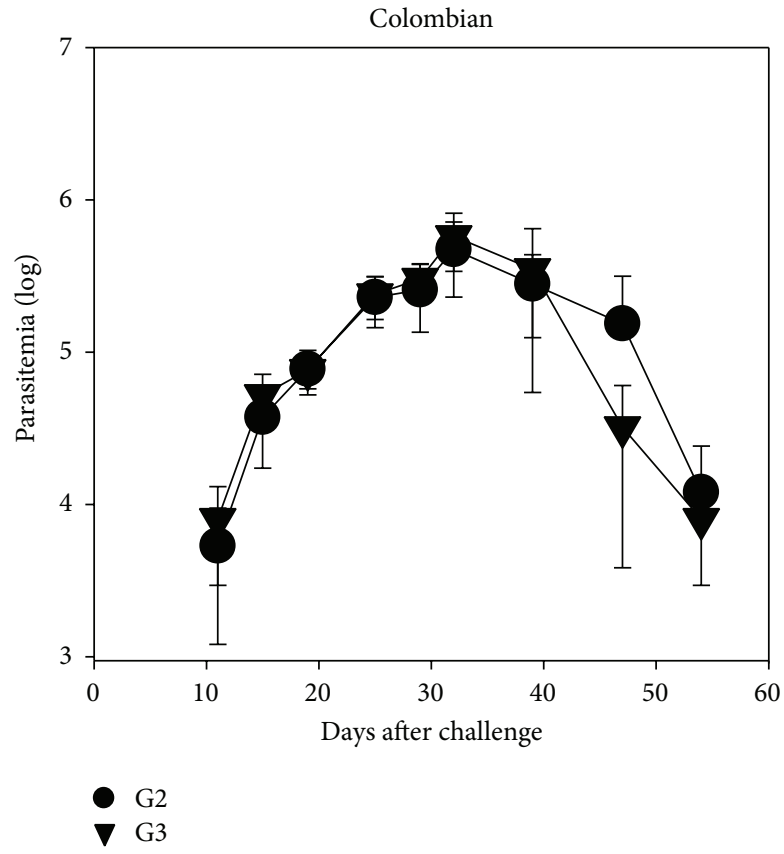

(c)

FIGURE 5: Impact of therapeutic vaccination in the immunity of resistant mice. (a) F1 (CB10XBALB/c) female mice were challenged s.c. with 1,000 trypomastigotes of the indicated parasite strain. Thirty days later, G2 mice received a mixture of control plasmid pcDNA3 and of pIL-12 $(300 \mu \mathrm{g})$, and G3 mice were immunized with a mixture of pIL-12, pIgSPCl9, and p154/13 (300 $\mu \mathrm{g})$. Twenty days later, these mice received, in these same spots, $100 \mu \mathrm{L}$ of a viral suspension containing a total of $2 \times 10^{8} \mathrm{pfu}$ of rec. adenovirus. For boosting, G2 mice received control adenovirus Ad $\beta$ gal, and G3 mice were immunized with a mixture of rec. adenovirus AdASP-2 and Ad-TS. (b) Mean parasitemia \pm SD of each mouse group $(n=6)$ challenged with parasites of the Brazil strain. (c) Mean parasitemia \pm SD of each mouse group $(n=6)$ challenged with parasites of the Colombian strain. 


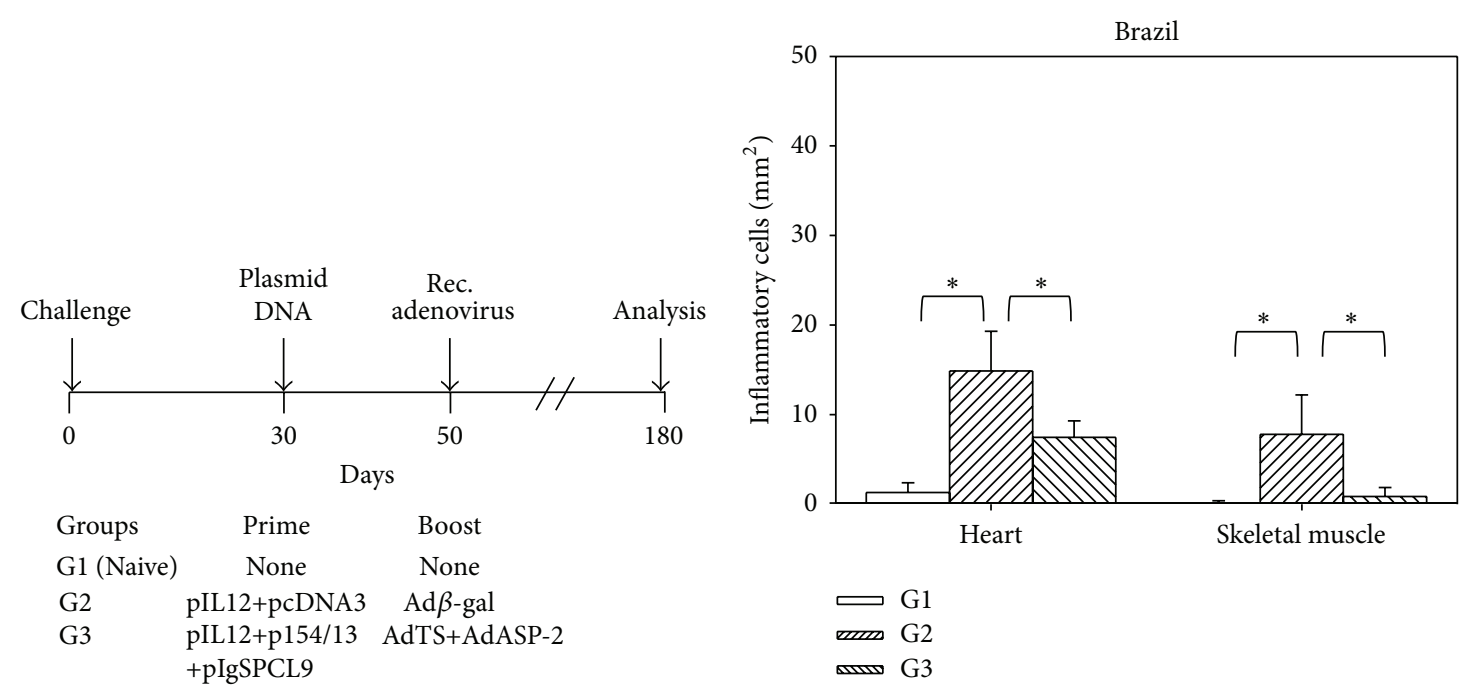

(a)

(b)

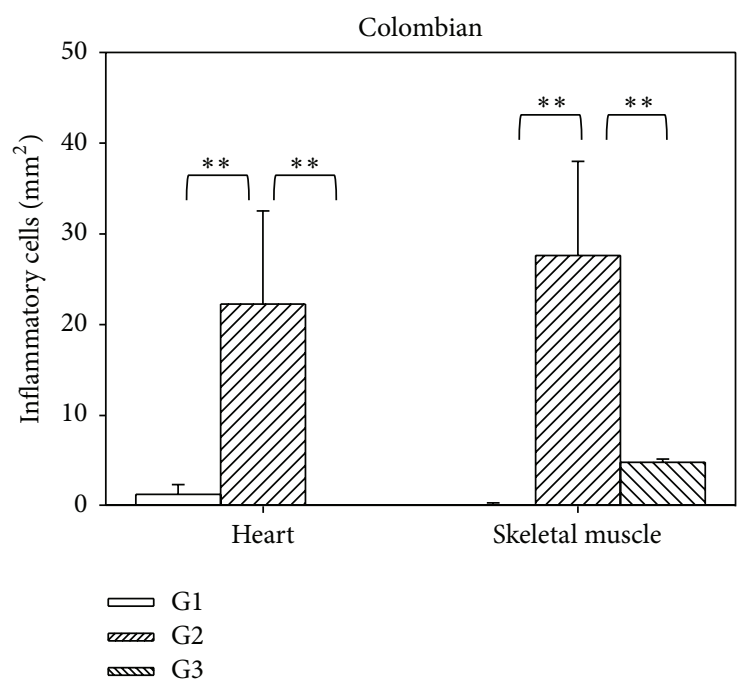

(c)

FIGURE 6: Frequencies of inflammatory cells in the hearts and skeletal muscles of resistant mice treated by the heterologous prime-boost regimen. (a) F1 (CB10XBALB/c) female mice were immunized i.m., as depicted. Details on the dose are shown Figure 5(a). (b) At 180 days, heart and skeletal muscle sections of mice challenged with the Brazil strain were stained with hematoxylin and eosin, and the number of inflammatory cells was quantified. Bars represent the mean of 6 mice/group \pm SD. Asterisks denote that there was a significant difference between the indicated groups $\left({ }^{*} P<0.05\right.$ or ${ }^{* *} P<0.01$ ). (c) The same as above, except that the mice were challenged with parasites of the Colombian strain.

infection, when the mice were euthanized. However, the damage to the heart had been established earlier and could no longer be reversed.

The reason why the $\mathrm{T}$ cells elicited by therapeutic genetic vaccination are not capable of reducing the symptoms is unknown at present. One possibility is that following infection, specific $\mathrm{T}$ cells are already committed to express the death receptor CD95, as we have recently described [29]. Once these cells express CD95, their viability is impaired, and they can no longer expand properly. It will be important to test this possibility because it has implications for the use of
$\mathrm{T}$ cell vaccines for therapeutic purposes during this or other chronic diseases [30-36].

The protective immune mechanisms mediating the effects of our new vaccination regimen were not addressed in the present study. However, it is plausible that $\mathrm{CD}_{4}^{+}$and $\mathrm{CD} 8^{+}$ $\mathrm{T}$ cells participate in this immune response, as we have previously described [15]. Corroborating this hypothesis is the fact that the addition of pIL-12 during priming led to a significant increase in the frequencies of multifunctional $\mathrm{CD}^{+} \mathrm{T}$ cells and a parallel increase in the protective immunity against acute infection. 
TABLE 2: Summary of the ECG records.

\begin{tabular}{|c|c|c|c|c|c|c|c|}
\hline \multirow{2}{*}{$\begin{array}{l}\text { Days after } \\
\text { challenge }\end{array}$} & \multirow{2}{*}{ Strain } & \multicolumn{3}{|c|}{ Sinus arrhythmia mouse groups } & \multicolumn{3}{|c|}{$P$ values } \\
\hline & & G1 & G2 & G3 & $\mathrm{G} 1 \times \mathrm{G} 2$ & $\mathrm{G} 1 \times \mathrm{G} 3$ & $\mathrm{G} 2 \times \mathrm{G} 3$ \\
\hline 90 & Brazil & $0 / 6$ & $10 / 6$ & $0 / 6$ & 0.001 & NS & 0.012 \\
\hline 120 & Brazil & $0 / 6$ & $10 / 6$ & $1 / 6$ & 0.001 & NS & 0.044 \\
\hline 150 & Brazil & $0 / 6$ & $11 / 6$ & $5 / 6$ & 0.001 & 0.007 & NS \\
\hline 180 & Brazil & $0 / 6$ & $4 / 6$ & $4 / 6$ & 0.03 & 0.03 & NS \\
\hline 90 & Colombian & $0 / 6$ & $3 / 6$ & $1 / 5$ & NS & NS & NS \\
\hline 120 & Colombian & $0 / 6$ & $3 / 6$ & $0 / 5$ & NS & NS & NS \\
\hline 150 & Colombian & $0 / 6$ & $12 / 6$ & $0 / 5$ & 0.001 & NS & 0.013 \\
\hline 180 & Colombian & $0 / 6$ & $16 / 6$ & $1 / 5$ & 0.001 & NS & 0.022 \\
\hline \multirow{2}{*}{$\begin{array}{l}\text { Days after } \\
\text { challenge }\end{array}$} & \multirow{2}{*}{ Strain } & \multicolumn{3}{|c|}{ Atrioventricular block mouse groups } & \multicolumn{3}{|c|}{$P$ values } \\
\hline & & G1 & G2 & G3 & $\mathrm{G} 1 \times \mathrm{G} 2$ & $\mathrm{G} 1 \times \mathrm{G} 3$ & $\mathrm{G} 2 \times \mathrm{G} 3$ \\
\hline 90 & Brazil & $0 / 6$ & $36 / 6$ & $46 / 6$ & 0.001 & 0.001 & NS \\
\hline 120 & Brazil & $0 / 6$ & $19 / 6$ & $22 / 6$ & 0.001 & 0.001 & NS \\
\hline 150 & Brazil & $0 / 6$ & $5 / 6$ & $6 / 6$ & 0.007 & 0.001 & NS \\
\hline 180 & Brazil & $0 / 6$ & $5 / 6$ & $3 / 6$ & 0.007 & NS & NS \\
\hline 90 & Colombian & $0 / 6$ & $20 / 6$ & $30 / 5$ & 0.001 & 0.001 & NS \\
\hline 120 & Colombian & $0 / 6$ & $27 / 6$ & $15 / 5$ & 0.001 & 0.001 & NS \\
\hline 150 & Colombian & $0 / 6$ & $6 / 6$ & $2 / 5$ & 0.001 & NS & NS \\
\hline 180 & Colombian & $0 / 6$ & $10 / 6$ & $10 / 5$ & 0.001 & 0.001 & NS \\
\hline
\end{tabular}

ECG record of mice challenged and treated as described in the legend of Figure 6(a). Values represent the number of episodes (sinus arrhythmia or atrioventricular block) recorded during one minute per total of mice analyzed and were compared by Fisher exact probability test.

In conclusion, this study reinforces and extends our previous work by demonstrating the improvement in acute and chronic symptoms after prophylactic genetic vaccination against $T$. cruzi infection using a vector expressing the TS and ASP-2 antigens.

\section{Conflict of Interests}

Ricardo Tostes Gazzinelli, Mauricio Martins Rodrigues, Alexandre Vieira Machado, and Oscar Bruna-Romero are named inventors on patent applications covering Trypanosoma cruzi vectored vaccines and immunization regimens. The other authors have no conflict of interests.

\section{Acknowledgments}

This work was supported by Grants from Fundação de Amparo à Pesquisa do Estado de São Paulo (2009/06820-4, 2013/13668/0, and 2012/22514-3) and Instituto Nacional de Ciência e Tecnologia em Vacina (INCTV-CNPq). Adriano Fernando Araújo, José Ronnie Vasconcelos, Mariana Ribeiro Dominguez, and Jonatan Ersching were recipients of fellowship from FAPESP. Oscar Bruna-Romero, Ricardo Tostes Gazzinelli, Milena Botelho Soares, and Mauricio Martins Rodrigues are recipients of fellowships from CNPq.

\section{References}

[1] P. J. Hotez, M. E. Bottazzi, C. Franco-Paredes, S. K. Ault, and M. R. Periago, "The neglected tropical diseases of Latin America and the Caribbean: a review of disease burden and distribution and a roadmap for control and elimination," PLoS Neglected Tropical Diseases, vol. 2, no. 9, article e300, 2008.

[2] K. Stuart, R. Brun, S. Croft et al., "Kinetoplastids: related protozoan pathogens, different diseases," Journal of Clinical Investigation, vol. 118, no. 4, pp. 1301-1310, 2008.

[3] A. R. L. Teixeira, M. M. Hecht, M. C. Guimaro, A. O. Sousa, and N. Nitz, "Pathogenesis of chagas' disease: parasite persistence and autoimmunity," Clinical Microbiology Reviews, vol. 24, no. 3, pp. 592-630, 2011.

[4] B. Y. Lee, K. M. Bacon, D. L. Connor, A. M. Willig, and R. R. Bailey, "The potential economic value of a Trypanosoma cruzi (Chagas disease) vaccine in Latin America," PLoS Neglected Tropical Diseases, vol. 4, no. 12, article e916, 2010.

[5] B. Y. Lee, K. M. Bacon, A. R. Wateska, M. E. Bottazzi, E. Dumonteil, and P. J. Hotez, "Modeling the economic value of a Chagas' disease therapeutic vaccine," Human Vaccines and Immunotherapeutics, vol. 8, no. 9, pp. 1293-1301, 2012.

[6] Y. Miyahira, "Trypanosoma cruzi infection from the view of $\mathrm{CD}^{+} \mathrm{T}$ cell immunity-an infection model for developing $\mathrm{T}$ cell vaccine," Parasitology International, vol. 57, no. 1, pp. 38-48, 2008.

[7] S. I. Cazorla, F. M. Frank, and E. L. Malchiodi, "Vaccination approaches against Trypanosoma cruzi infection," Expert Review of Vaccines, vol. 8, no. 7, pp. 921-935, 2009.

[8] J. C. Vázquez-Chagoyán, S. Gupta, and N. J. Garg, "Vaccine development against Trypanosoma cruzi and Chagas disease," Advances in Parasitology, vol. 75, pp. 121-146, 2011.

[9] I. Quijano-Hernandez and E. Dumonteil, "Advances and challenges toward a vaccine against Chagas disease," Human Vaccines, vol. 7, no. 11, pp. 1184-1191, 2011. 
[10] M. M. Rodrigues, A. C. Oliveira, and M. Bellio, "The immune response to Trypanosoma cruzi: role of toll-like receptors and perspectives for vaccine development," Journal of Parasitology Research, vol. 2012, Article ID 507874, 12 pages, 2012.

[11] E. Dumonteil, M. E. Bottazzi, and B. Zhan, "Accelerating the development of a therapeutic human Chagas disease: rationale and prospects," Expert Reviews Vaccines, vol. 11, pp. 1043-1055, 2012.

[12] C. P. Brandan and M. A. Basombrío, "Genetically attenuated Trypanosoma cruzi parasites as a potential vaccination tool," Bioengineered, vol. 3, no. 4, pp. 242-246, 2012.

[13] F. Costa, G. Franchin, V. L. Pereira-Chioccola, M. Ribeirão, S. Schenkman, and M. M. Rodrigues, "Immunization with a plasmid DNA containing the gene of trans-sialidase reduces Trypanosoma cruzi infection in mice," Vaccine, vol. 16, no. 8, pp. 768-774, 1998.

[14] A. E. Fujimura, S. S. Kinoshita, V. L. Pereira-Chioccola, and M. M. Rodrigues, "DNA sequences encoding $\mathrm{CD}^{+}$and $\mathrm{CD} 8^{+} \mathrm{T}-$ cell epitopes are important for efficient protective immunity induced by DNA vaccination with a Trypanosoma cruzi gene," Infection and Immunity, vol. 69, no. 9, pp. 5477-5486, 2001.

[15] B. C. De Alencar, P. M. Persechini, F. A. Haolla et al., "Perforin and gamma interferon expression are required for CD4+ and CD8+ T-cell-dependent protective immunity against a human parasite, Trypanosoma cruzi, elicited by heterologous plasmid DNA prime-recombinant adenovirus 5 boost vaccination," Infection and Immunity, vol. 77, no. 10, pp. 4383-4395, 2009.

[16] F. A. Haolla, C. Claser, B. C. G. de Alencar et al., "Strain-specific protective immunity following vaccination against experimental Trypanosoma cruzi infection," Vaccine, vol. 27, no. 41, pp. 5644-5653, 2009.

[17] M. R. Dominguez, E. L. Silveira, J. R. de Vasconcelos et al., "Subdominant/cryptic CD8 T cell epitopes contribute to resistance against experimental infection with a human protozoan parasite," PLoS ONE, vol. 6, no. 7, Article ID e22011, 2011.

[18] M. R. Dominguez, J. Ersching, R. Lemos et al., "Re-circulation of lymphocytes mediated by sphingosine-1-phosphate receptor1 contributes to resistance against experimental infection with the protozoan parasite Trypanosoma cruzi," Vaccine, vol. 30, no. 18, pp. 2882-2891, 2012.

[19] P. O. Rigato, B. C. de Alencar, J. R. C. de Vasconcelos et al., "Heterologous plasmid DNA prime-recombinant human adenovirus 5 boost vaccination generates a stable pool of protective long-lived $\mathrm{CD}^{8+} \mathrm{T}$ effector memory cells specific for a human parasite, Trypanosoma cruzi," Infection and Immunity, vol. 79, no. 5, pp. 2120-2130, 2011.

[20] J. R. Vasconcelos, M. R. Dominguez, R. L. Neves et al., "Adenovirus vector-induced $\mathrm{CD} 8^{+} \mathrm{T}$ effector memory cell differentiation and recirculation, but not proliferation, are important for protective immunity against experimental Trypanosoma cruzi infection," Human Gene Therapy, vol. 25, no. 4, pp. 350-363, 2014.

[21] B. Zingales, S. G. Andrade, M. R. S. Briones et al., "A new consensus for Trypanosoma cruzi intraspecific nomenclature: second revision meeting recommends TcI to TcVI," Memórias do Instituto Oswaldo Cruz, vol. 104, no. 7, pp. 1051-1054, 2009.

[22] M. A. Miles, M. S. Llewellyn, M. D. Lewis et al., "The molecular epidemiology and phylogeography of Trypanosoma cruzi and parallel research on Leishmania: looking back and to the future," Parasitology, vol. 136, no. 12, pp. 1509-1528, 2009.

[23] A. L. Rakhmilevich, J. Turner, M. J. Ford et al., "Gene gunmediated skin transfection with interleukin 12 gene results in regression of established primary and metastatic murine tumors," Proceedings of the National Academy of Sciences of the United States of America USA, vol. 93, no. 13, pp. 6291-6296, 1996.

[24] S. B. Boscardin, S. S. Kinoshita, A. E. Fujimura, and M. M. Rodrigues, "Immunization with cDNA expressed by amastigotes of Trypanosoma cruzi elicits protective immune response against experimental infection," Infection and Immunity, vol. 71, no. 5, pp. 2744-2757, 2003.

[25] A. V. Machado, J. E. Cardoso, C. Claser, M. M. Rodrigues, R. T. Gazzinelli, and O. Bruna-Romero, "Long-term protective immunity induced against Trypanosoma cruzi infection after vaccination with recombinant adenoviruses encoding amastigote surface protein-2 and trans-sialidase," Human Gene Therapy, vol. 17, no. 9, pp. 898-908, 2006.

[26] J. F. Vasconcelos, B. S. Souza, and T. F. Lins, "Administration of granulocyte colony-stimulating factor induces immunomodulation, recruitment of T regulatory cells, reduction of myocarditis and decrease of parasite load in a mouse model of chronic Chagas disease cardiomyopathy," FASEB Journal, vol. 27, no. 12, pp. 4691-4702, 2013.

[27] C. H. Olsen, "Statistics in infection and immunity revisited," Infection and Immunity, vol. 82, no. 3, pp. 916-920, 2014.

[28] N. Winstone, A. J. Wilson, G. Morrow et al., "Enhanced control of pathogenic Simian immunodeficiency virus SIVmac239 replication in macaques immunized with an interleukin-12 plasmid and a DNA prime-viral vector boost vaccine regimen," Journal of Virology, vol. 85, no. 18, pp. 9578-9587, 2011.

[29] J. R. Vasconcelos, O. Bruña-Romero, A. F. Araújo et al., "Pathogen-induced proapoptotic phenotype and high CD95 (Fas) expression accompany a suboptimal $\mathrm{CD}^{+}$T-cell response: reversal by adenoviral vaccine," PLoS Pathogen, vol. 8, no. 5, Article ID e1002699, 2012.

[30] P. Stephens, "Vaccine R\&D: past performance is no guide to the future," Vaccine, vol. 32, no. 19, pp. 2139-2142, 2014.

[31] E. S. Pronker, T. C. Weenen, H. Commandeur, E. H. Claassen, and A. D. Osterhaus, "Risk in vaccine research and development quantified," PLoS ONE, vol. 8, no. 3, Article ID e57755, 2013.

[32] M. Karkada, N. L. Berinstein, and M. Mansour, "Therapeutic vaccines and cancer: focus on DPX-0907," Biologics, vol. 8, pp. 27-38, 2014.

[33] D. Majhen, H. Calderon, N. Chandra et al., "Adenovirus-based fighting infectious diseases and cancer: progress in the field," Human Gene Therapy, vol. 25, no. 4, pp. 301-317, 2014.

[34] G. Carcelain and B. Autran, "Immune interventions in HIV infection," Immunological Reviews, vol. 254, no. 1, pp. 355-371, 2013.

[35] C. Montagnani, E. Chiappini, L. Galli, and M. de Martino, "Vaccine tuberculosis: what's new?" BMC Infectious Diseases, vol. 14, supplement 1, article S2, 2014.

[36] J. R. Vasconcelos, M. R. Dominguez, A. F. Ara et al., "Relevance of long-lived CD8(+) T effector memory cells for protective immunity elicited by heterologous prime-boost vaccination," Frontiers in Immunology, vol. 3, p. 358, 2012. 


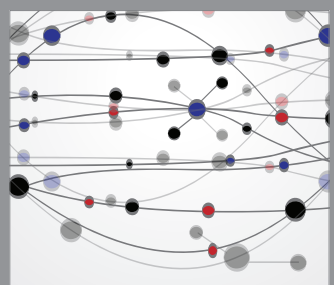

The Scientific World Journal
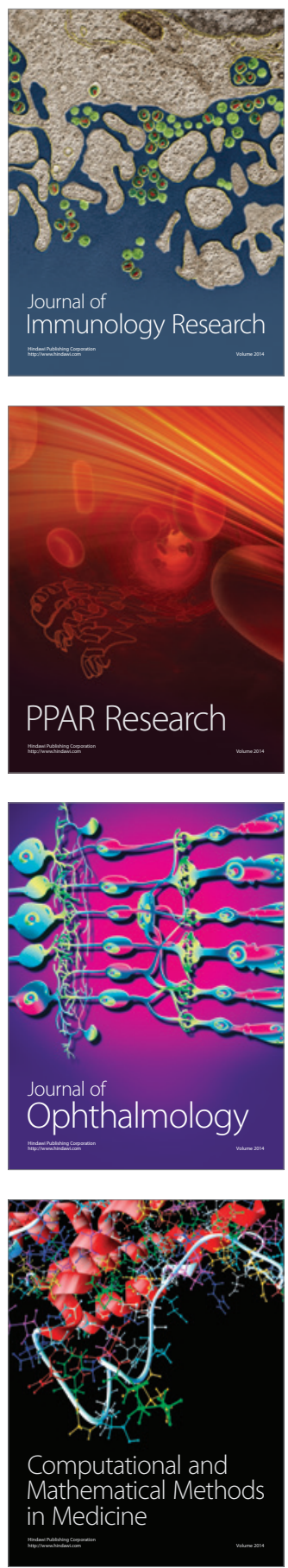

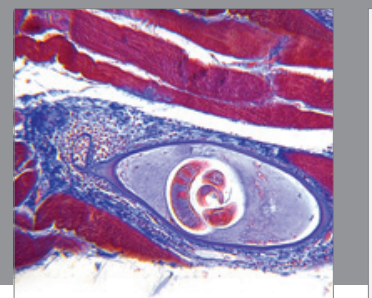

Gastroenterology

Research and Practice
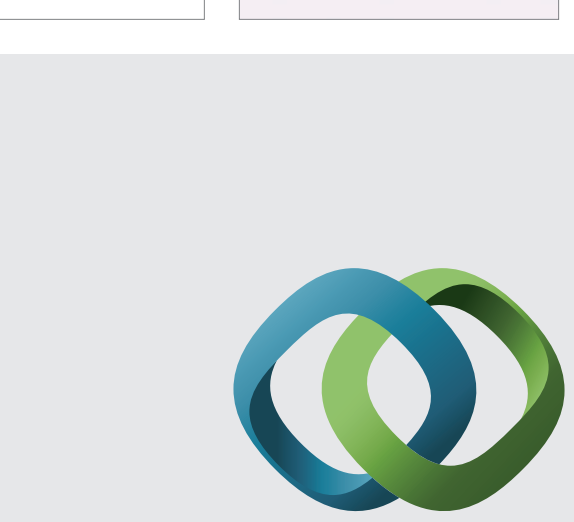

\section{Hindawi}

Submit your manuscripts at

http://www.hindawi.com
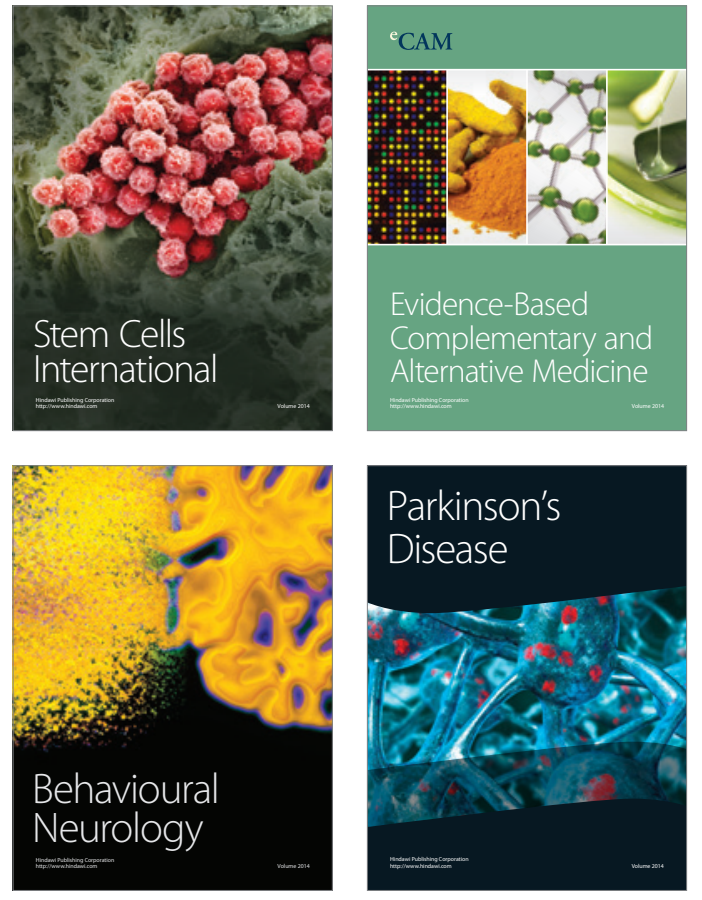
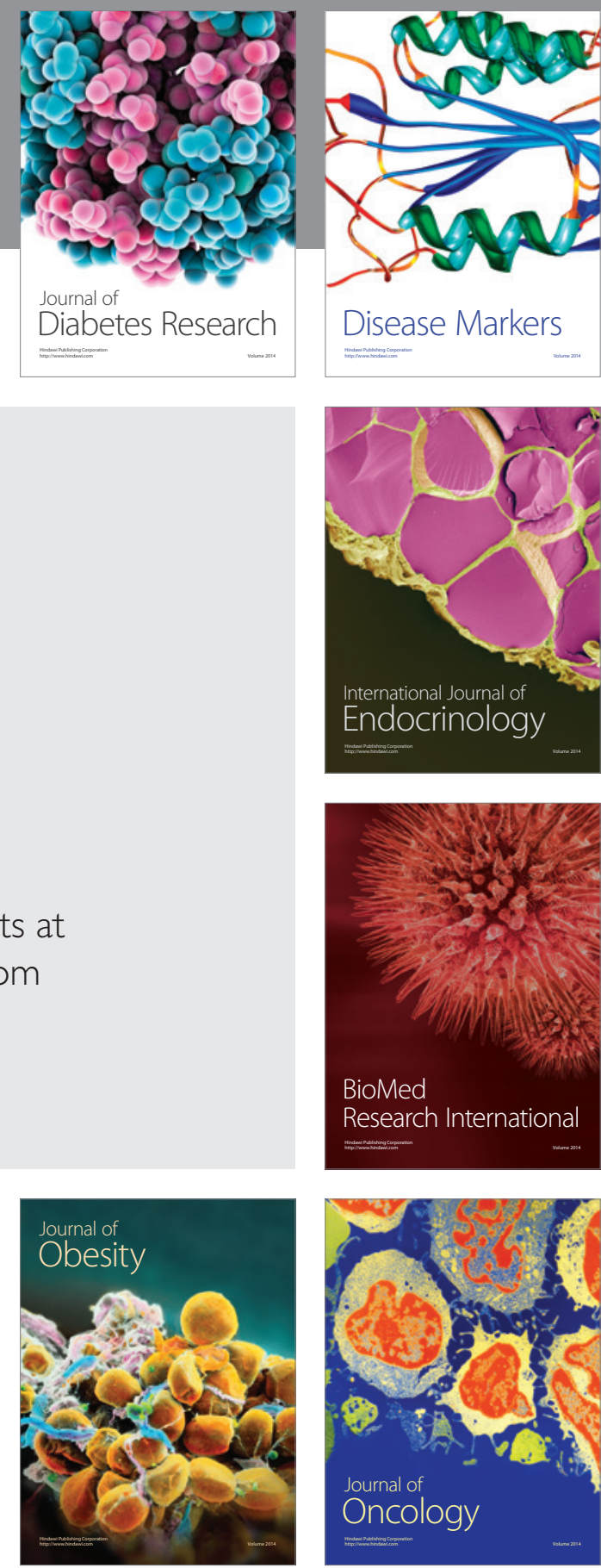

Disease Markers
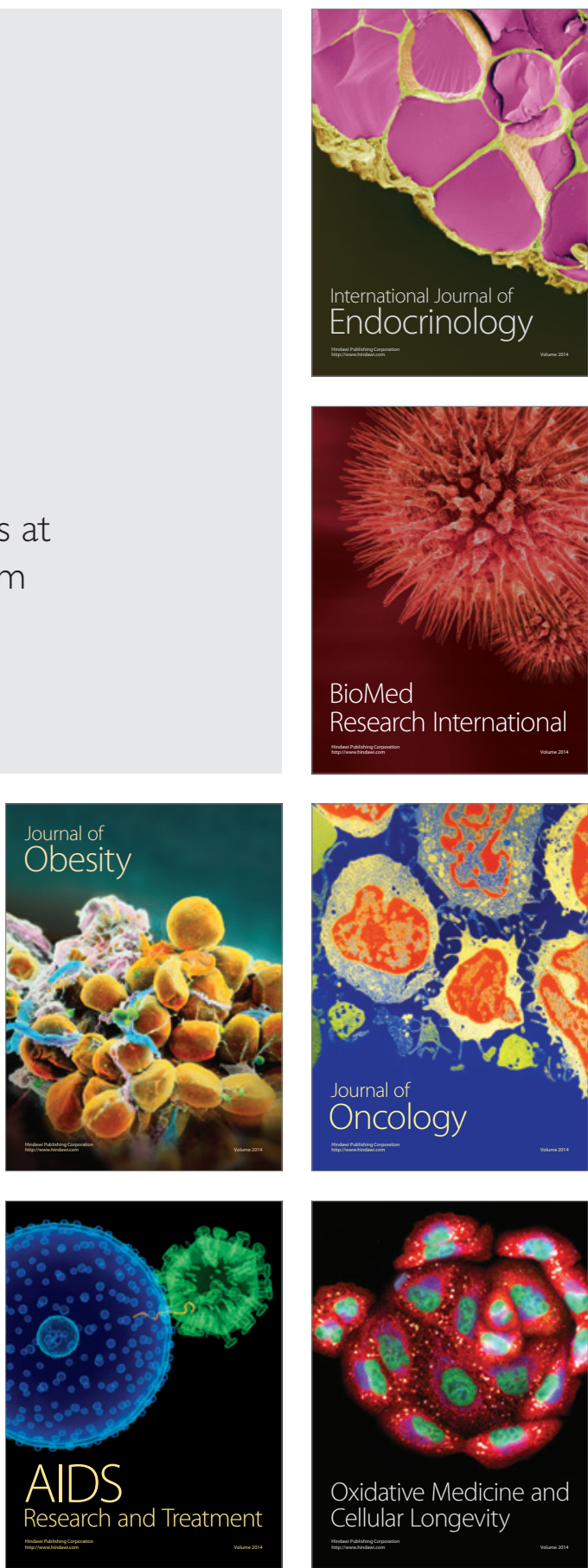